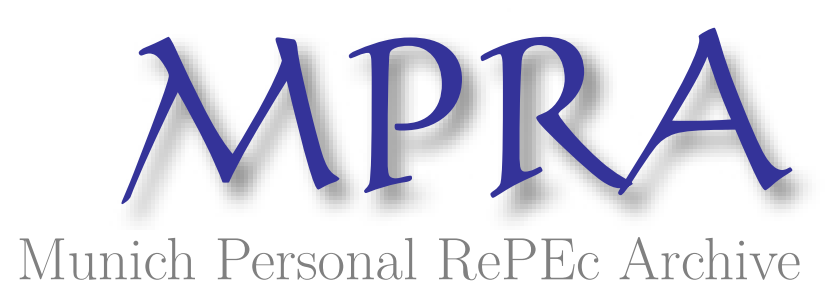

\title{
How could the South respond to secular stagnation in the North?
}

Mayer, Joerg

3 March 2015

Online at https://mpra.ub.uni-muenchen.de/62113/

MPRA Paper No. 62113, posted 04 Mar 2015 15:09 UTC 


\title{
How could the South respond to secular stagnation in the North?
}

\author{
Jörg Mayer \\ (joerg.mayer@unctad.org)
}

\begin{abstract}
Developed countries face the risk of a sustained lack of aggregate demand, i.e. secular stagnation. Demand-oriented growth models emphasizing the balance-of-payments constraint raise concerns about attendant adverse growth impacts on developing countries from reduced export growth. These concerns are well-founded, albeit less serious than the simplest version of these models would imply. Relaxing their assumptions and emphasizing cumulative causation forces from domestic-demand growth and relative price effects indicates how changed policies can maintain rapid growth while reducing the import content of demand. Crucial is investment that reduces gaps between the composition of domestic production and domestic demand and emphasizes sectors with cumulative-causation effects, combined with incomes policy and capital-account management. Drawing down excessive foreign-exchange reserves and obtaining concessionary loans from development banks can finance required capital-goods imports. Enhanced South-South integration may be an important complement for small countries.
\end{abstract}

Acknowledgement: The author is grateful to Raphie Kaplinsky, Sheila Page, Tony Thirlwall and Adrian Wood for helpful comments on earlier versions. The opinions expressed are solely those of the author and do not necessarily reflect the views of UNCTAD or its Member States. 


\section{Introduction}

Seven years after the onset of the global financial crisis, the growth path of the world economy remains on noticeably lower levels than before the crisis. Many developed countries continue to lack robust demand growth and experience inflation significantly below targeted rates, despite several years of accommodative monetary policy, improved financial conditions and some relaxation of fiscal consolidation. Developing countries maintained rapid growth up to 2010-2011 through the adoption of countercyclical policies, which raised domestic demand and mitigated declining growth stimuli from the external economic environment. However, these policies have been gradually unwound as many developing countries have experienced pressure on domestic prices or trade balances that could be contained only by accepting lower domestic demand growth. The emphasis of the development literature on the importance of developed-country growth for developing-country growth indicates that developing countries may experience a progressive downward slide of growth if the lack of aggregate demand in developed countries persists.

Concerns that economic growth in developed countries will remain weak for a protracted period of time have been summarized as "secular stagnation", i.e. an extended period of low growth reflecting persistently weak demand that could turn into stagnation because weak actual output growth reinforces the erosion of potential output growth. There is no agreement as to whether the current economic situation in developed countries actually reflects secular stagnation (for discussion see, e.g. Teulings and Baldwin, 2014). Yet, the risk of protracted subdued demand growth in these economies and the spillover effects of policies that developed countries may adopt to address this phenomenon provide enough reason for developing countries to consider a response to diminished prospects for export-led growth.

The paper's main contributions are its focus on the impact that secular stagnation may have on developing countries' growth prospects and its use of a unified framework based on two traditions that emphasize the role of exports in economic growth. These are the growth model based on the balance-of-payments constraint (Thirlwall, 1979), which underlines the relationship between imports and exports in the growth process, and the model of cumulative causation (Kaldor, 1970; Myrdal, 1957), which emphasizes the positive association between growth of a country's GDP and that of its manufacturing sector.

The paper's main argument is that concerns raised by models emphasizing the balance-ofpayments constraint about developing countries' growth prospects are well-founded, albeit 
less serious than the simplest version of the model would imply. Changing assumptions to emphasize cumulative causation forces from domestic-demand growth and allow for relative price effects indicate that developing countries can maintain rapid growth by compensating for lower export growth by faster domestic-demand growth, provided that they can also reduce the import content of demand. Achieving this requires changing policies towards a focus on investment that moves the composition of domestic production closer to the emerging composition of domestic demand and emphasizes sectors that are sufficiently large to enjoy cumulative-causation effects. Such investment should be accompanied by incomes policy and capital-account management. Drawing down excessive foreign-exchange reserves or obtaining concessionary loans from development banks could provide the financing for capital-goods imports that some developing countries may require. Resource-based economies will find growth rebalancing more challenging than those that have developed manufacturing during periods of export-led growth. Small countries may require further growth support from enhanced South-South integration. Rebalancing developing countries' growth strategies will be complicated if developed countries continue addressing the risk of secular stagnation by relying on monetary expansion and/or if their policies involve shifting the composition of their aggregate demand towards a greater importance of external demand.

The next section discusses the risk of secular stagnation in developed countries, its potential reasons and attendant policy options. Section 3 examines the relationship between developedcountry and developing-country growth from the perspective of growth models and combines two demand-oriented models to consider the channels through which this relationship works. Section 4 discusses policy responses by developing countries, and section 5 concludes.

\section{The risk of secular stagnation in developed countries}

The hypothesis of "secular stagnation" describes the risk that very sluggish economic growth becomes the new norm in developed countries because their traditional macroeconomic toolkit, and especially monetary policy, becomes ineffective (Summers, 2014a and b; Krugman, 2014a). ${ }^{1}$ It asserts that the financial crisis of 2007-2008 was a second-order event

\footnotetext{
${ }^{1}$ The term "secular stagnation" was coined by Hansen (1939) who worried that the United States was facing slowing demographic and labour-force growth combined with constraints on farmland expansion that would generate under-investment and aggregate demand deficiency that would cause economic growth to decline to very slow rates. While fiscal expansion related to World War II and accelerated population growth during the 1950s prevented Hansen's concern to materialize, the hypothesis that global economic recovery over the past
} 
and that the main culprit for the slow recovery from the crisis has been a decade-long tendency of inadequate aggregate demand growth. ${ }^{2}$ The United States has addressed the resulting adverse effects on output growth by successive waves of accommodative monetary policy. Each of these episodes allowed demand gaps to be compensated temporarily by an unsustainable debt-fuelled expansion of consumption spending based on easier access to loans and the wealth effects of asset price bubbles. ${ }^{3}$ Other large developed countries, such as Germany and Japan, have supported domestic aggregate demand by large trade surpluses. The current situation where accommodative monetary policy is hitting the zero-interest-rate bound and facing a liquidity trap makes it increasingly difficult to generate the effects needed to restore full employment and rapid growth through the usual macroeconomic toolkit. This is the case not only for the United States, where monetary expansion would aim at lower output gaps, but also for Germany (or the Euro-area more generally) and Japan, where monetary expansion would tackle very low inflation. Taken together, policymakers in developed countries, and especially the United States, are facing a trade-off between accepting prolonged sluggish output growth and creating ever greater asset market bubbles, unless they successfully address the root causes of secular stagnation.

Among the various causes given for secular stagnation (see, e.g. Summers, 2014a; Teulings and Baldwin, 2014), three relate to reduced long-term potential growth that is holding back current fixed capital investment: (i) the slower growth of the labour force, due to both a declining rate of population growth and a decline in labour force participation, which requires less capital to equip workers; (ii) structural changes in production processes causing technologically leading enterprises to operate on lower capital-output ratios and reduce their expenditure on fixed investment; and (iii) the decline in the relative prices of capital goods so

\footnotetext{
seven years has been held back by deficient aggregate demand has revived interest in this issue. For a review on the diagnosis, causes and possible remedies of secular stagnation, see e.g. Teulings and Baldwin (2014).

${ }^{2}$ IMF (2014) considers the period of secular stagnation to have begun in the mid-1980s, when real interest rates in developed countries started to decline following the adoption of disinflationary policies in these countries. However, the mid-1980s also mark the beginning of the long-run decline of the wage share in developed countries (ILO, 2015). Disinflationary policies may be at the origin of this decline as they became theoretically justifiable following the growing attention given during the 1970s and 1980s to New Classical Macroeconomics that, as opposed to Keynesian economics, asserts that only the aggregate price level and labour market flexibility, and not aggregate demand, have an impact on output and employment growth.

3 Though adopted for different reasons, the fiscal expansion in the form of tax cuts during 2001-2003 also helped staving off a deep recession in the United States following the dot-com crash in 2000.
} 
that purchasing a given unit of such goods implies lower levels of fixed investment expenditure. $^{4}$

Two additional factors have been identified as causing a lack of aggregate demand that, in turn, holds back actual output growth and further reduces current fixed capital investment. First, in his hypothesis of a balance-sheet recession, Koo (2013) argues that the current ineffectiveness of monetary policy in removing the shortage of aggregate demand results from the focus of highly indebted private firms and households on paying down their debt, and their resulting unwillingness to borrow even when interest rates fall. While sensible at the individual level, such a strategy of minimizing debt causes an enduring lack of aggregate demand at the macroeconomic level if the new savings fail to create new investment or consumption expenditure. This factor may primarily apply to immediate post-crisis periods, but its effects can extend for prolonged period of times if, as currently the case, slow income recovery and very low inflation rates retard the deleveraging process.

Second, distributional changes, both between labour and capital income and between those with more wealth and those with less, imply a decline in the share of income that goes to those with a higher propensity to spend and a lower propensity to save. In this situation, avoiding a decline in aggregate demand growth requires a trade surplus, fiscal expansion or increased borrowing to boost debt-financed consumer spending. ${ }^{5}$ This view (e.g. Stiglitz, 2012: 85) identifies the deep cause of secular stagnation not so much as a liquidity trap but rather as income stagnation. It argues that the decline in the wage share in developed countries by about ten percentage points since the 1980s has considerably constrained income-based consumer demand with attendant adverse effects on private investment. These adverse demand effects from worsened functional income distribution have been reinforced by (i) worsened personal income distribution, as the share in total income of the richest households has strongly increased and that of middle-class households decreased, and (ii) reliance of policies adopted to address the demand shortfall on monetary expansion, as this

\footnotetext{
${ }^{4}$ Gordon (2014) argues that slowing economic potential relates to a reduced pace of technological progress as rapid productivity growth during the period 1930-1980 was exceptional and is likely to decline back to its relative low historical norm, so that the growth contribution of technological progress is unlikely to increase. While this concept is often confused as providing a further reason for secular stagnation, it is a supply-side concept, while secular stagnation is a demand-side concept (Krugman, 2014a).

${ }^{5}$ To the extent that an individual's savings behaviour is well explained by life-time consumption smoothing, excess savings stemming from distributional changes may have been accentuated by the aging of developed country populations. As a further reason for excess savings, Summers (2014a) mentions current-account surpluses of emerging economies combined with their desire to invest the resulting reserves in safe assets in the United States and other developed countries. However, this factor is closely related to distributional changes in developed countries (e.g., Kumhof et al, 2012) and therefore is not further addressed here.
} 
policy mix has led firms to use their profits for investment in financial assets, rather than production facilities, which spurs asset-price bubbles and causes worsening wealth distribution (e.g., ILO, 2015).

While a distinction of causes affecting potential output growth on the one hand and those affecting actual output growth on the other hand may be useful for heuristic reasons, there are likely to be feedback relationships. This is the case especially if one considers that investment responds to the expected return to investment, i.e. that higher expected aggregate demand induces investment in productive capacity, and that the low investment rates in developed countries over the past five years have shunted their economies into low-growth paths in which low aggregate demand growth and low potential output growth have fed back into one another.

A first option for developed countries to deal with the risk of secular stagnation is prolonged monetary expansion. ${ }^{6}$ This would reduce the actual real interest rate and, combined with a higher inflation target aimed at achieving permanently higher inflation expectations, make a zero nominal interest rate correspond to a lower real interest rate. This would address the liquidity trap, allow monetary policy to gain back some of its effectiveness and reduce the risk of insufficient demand growth causing deflation and further declining demand (Krugman, 2014b). However, this strategy has been pursued over the past five years and the continued sluggishness in economic recovery indicates that combating insufficient demand solely through expansionary monetary policy is insufficient to stimulate real economic activity. Instead, it probably undermines financial stability, for example, by increasing risk taking of investors searching for yield and making Ponzi schemes more attractive (Summers, 2014b). Moreover, the distributional effects of the ensuing asset price bubbles tend to accentuate, rather than remedy, the insufficiency of aggregate demand.

A second group of policies addressing secular stagnation aims at raising the level of aggregate demand at any given level of the real interest rate. Given the constraints on conventional monetary policy and the uncertainty related to unconventional monetary expansion, policymakers should use to the fullest extent possible the less uncertain alternative

\footnotetext{
${ }^{6}$ Some observers propose relying on market forces to address protracted sluggish growth, as macroeconomic policy is judged ineffective at best. Instead, policymakers should consider policies designed to stimulate productivity growth and labour-force participation to boost investment demand mainly through structural reforms, such as improved education and labour mobility, as well as more competition and a more investorfriendly business climate (e.g. Mokyr, 2014). However, to the extent that the risk of secular stagnation is real, following this supply-based strategy will prolong the period of insufficient aggregate demand.
} 
policy instrument, i.e. fiscal policy. Complementing expansionary monetary policy by looser fiscal policies would aim at both avoiding deflation and facilitating debt deleveraging. Koo (2013), for example, suggests combining expansionary monetary policy with countercyclical fiscal policy for a period that significantly exceeds the usual temporary, short-term dimension. Fiscal expansion should extend until private firms and households have paid down debt and repaired their balance sheets, at which point they begin spending normally again, and governments could start restoring their own balance sheets and let monetary policy be alone in charge of sustaining demand. Concentrating fiscal expansion on increased public investment in physical infrastructure (IMF, 2014), would address secular stagnation by increasing the rate of current aggregate demand growth and alleviating medium-term supply constraints. This proposal asserts that when unemployment is high, as it is in most developed countries, the demand stimulus will be greater if investment is paid for by borrowing, rather than reducing other spending or raising taxes. Most notably, it asserts that properly designed infrastructure investment will reduce rather than increase government debt burdens. However, in spite of its sizable potential economic benefits large-scale and/or prolonged fiscal stimulus may be politically difficult to adopt, e.g. because of institutional constraints related to the European Fiscal Stability Treaty and the debt brake in the German constitution, political gridlocks and related budget sequestrations in the United States, and already elevated levels of public debt in Japan. ${ }^{7}$

Another measure would be increasing households' disposable income to stimulate incomefinanced household consumption. This could be achieved by enhanced transfer payments, but especially higher (minimum) wages, bringing the long-term unemployed back into work and augmenting the participation rate. However, there is no evidence for a sizable increase in disposable incomes (e.g., ILO, 2015).

In the absence of significant demand impulses from government expenditure or household disposable income, aggregate demand may be spurred by increased private investment. Regarding the United States, the onset of the Great Recession heralded the adoption of a wide range of policies whose common objective is to increase private investment for the "renaissance of American manufacturing". These measures target domestic manufacturing because of its crucial role in innovation, exports and, especially, the creation of well-paid

\footnotetext{
${ }^{7}$ Indeed, Germany achieved a balanced budget for 2014 and Japan has reconsidered the phasing in of a sales tax, adopted for fiscal consolidation reasons, whose first element capped consumption spending in the second and third quarter of 2014 and led the country into recession.
} 
jobs (Sperling, 2013). Such initiatives are part of more general measures aimed at redressing the decline in well-paid manufacturing jobs, which has been observed for major developed countries. $^{8}$

These measures are closely related to a third measure, i.e. rebalancing the growth pattern by "shifting the composition of aggregate demand toward the tradable sector and, specifically, toward external demand" that Hlatshwayo and Spence (2014: 274) see as an important part of economic recovery in the United States. This could be achieved by further restraint on wage growth under the rubric of "boosting competitiveness", exchange-rate depreciation or through trade agreements, including with a view to increasing exports to developing countries. Indeed, Edwards and Lawrence (2013: 24) argue that "consensus projections suggest that even if the other advanced economies can achieve their full potential growth rates, the emerging-market economies will contribute almost 70 percent of global growth over the next 20 years. This growth should stimulate US exports and reduce the need for adjustment".

Taken together, the discussion in this section indicates that developed-country policymakers dispose of a wide array of measures to address the risk of secular stagnation. A desirable solution would include measures that increase the wage share and disposable personal income combined with backing accommodative monetary policy by more expansionary fiscal measures. However, in spite of some job creation there is little evidence for wage growth ${ }^{9}$ and fiscal expansion has been blocked for institutional or political reasons. This means that the policy mix combating the risk of secular stagnation is likely to differ across developed countries but to include continued easy monetary conditions and a sizable contribution of exports to aggregate demand growth, at least partly fuelled by exchange-rate depreciation that may be associated with monetary expansion.

\footnotetext{
${ }^{8}$ Recent job creation in the United States has largely been confined to low-paying services activities, while the share of low-paying part-time jobs in total employment has strongly increased in Germany (ILO, 2015).

${ }^{9}$ A crucial question for monetary policy is the timing of phasing out monetary expansion and how to interpret signals from the labour market in that respect. Recent research for both Europe and the United States suggests that the influence on wage and price determination by the long-term unemployed, and in particular by discouraged job-seekers and part-time employees who seek full-time work, is considerable lower than that of the short-term unemployed, so that the optimal time lag between signals from the labour market indicating economic recovery and monetary tightening may have become considerably longer than evidence from past economic recoveries would suggest (e.g., Rudebusch and Williams, 2014).
} 


\section{Does growth in the North determine growth in the South?}

\section{(a) Supply-side and demand-side perspectives}

Most models of economic growth would consider the growth rate of the North largely irrelevant to the determination of growth in the South. Such models are supply-driven, with output growth a function of factor inputs and factor productivity. Reduced growth in the developed countries would enter supply-based growth analyses for developing countries only through a deterioration of their terms of trade, which would lead to a loss of real income though not necessarily slower growth of output volumes, and a decline in market size, which would reduce capital accumulation or productivity growth, such as through reduced economies of scale at the firm level. Supply-oriented models would base a continuation of rapid growth in developing countries primarily on skills upgrading and structural reforms designed to develop more efficient ways to produce and deliver goods and services.

However, the sluggish recovery in developed countries from the global financial crisis has revived interest in demand-driven growth. Regarding developed countries, shorter-term issues have seen renewed acceptance of the idea that economies often suffer from a lack of effective demand and that price adjustments that would correct shortfalls in demand operate slowly, if at all. Thus, demand stimulus, such as fiscal expansion, should be used in addition to traditional monetary policy and regulatory tools to accelerate economic recovery (e.g., Krugman, 2009; Blanchard, Dell'Ariccia and Mauro, 2014). Longer-term issues of demandconstrained growth in developed countries were discussed in the previous section.

Some of this renewed acceptance of demand-side growth determinants is reminiscent of the traditional argument of development economics that Southern growth depends on Northern growth, via Northern demand for Southern exports. Identifying trade as "the engine of growth" for developing countries, Lewis (1980) discussed the consequences of what many at the time considered a secular decline in the rate of economic growth in developed countries, starting in the mid-1970s. He argued that a growth slowdown in developed countries would imply lower export opportunities for developing countries and suggested accelerated SouthSouth trade as an alternative engine of growth. This change in export destination should be accompanied by a change in export composition from primary commodities to capital goods. To prevent that declining revenues from exports to developed countries slow down developing country growth by reducing the funds available for capital goods imports from 
developed countries, developing-country production and South-South trade of such goods should increase substantially.

Riedel (1984) criticized Lewis (1980) for assuming very limited substitutability between tradable goods in developing and developed countries. This assumption reduces the scope for developing countries to benefit from relative price effects and engage in price competition to expand exports despite the slowdown in developed countries, i.e. by increasing their market shares. However, there are limits to the increase in developing countries' shares on developed country markets, as argued by the fallacy-of-composition literature. If, in a situation of sluggish import growth in developed countries, all, in particular large, developing countries try to substantially increase manufactured exports, they risk rising protective resistance from developed countries and/or a deterioration in their terms of trade to such an extent that the benefits of larger export volumes is more than offset by lower export prices (see e.g. Mayer, 2002; Cline, 2010).

Contrary to both Lewis' expectations and concerns from the fallacy-of-composition literature, the growth slowdown in developed countries was short-lived, their imports from developing countries grew rapidly over the two decades prior to 2007, and the attendant increase in the proportion of manufactured exports in the composition of developing countries' aggregate demand sustained the role of trade as an engine of growth for developing countries. However, this does not invalidate Lewis' general concern. Rather, the secular-stagnation hypothesis implies that developed countries have addressed the growth slowdown that started in the mid1970s-1980s by policies that are no longer effective. But distinct from Lewis' proposal, the argument in what follows is that it is the creation of manufacturing capacity, growth of per capita incomes and the accumulation of sizable current-account surpluses during the precrisis period of export-led growth that now allow developing countries to focus their response to secular stagnation in developed countries on increased domestic demand, especially consumption, rather than on expanded production and South-South trade of capital goods that probably still are beyond the reach of developing countries.

\section{(b) Southern growth and exports: insights from demand-oriented growth models}

The general revival of interest in demand-based growth determinants and the argument of development economics that Southern growth depends on Northern growth, via Northern 
demand for Southern exports, make it worth looking at two related models in which this link can be formally analysed. The first of these models is export-led cumulative causation (ELCC) which, following Kaldor (1970), holds that an exogenous increase in export demand, especially for manufactures, stimulates investment that leads to faster output growth, allows producing with increasing returns of scale and induces technological innovation, thereby causing faster productivity growth which, in turn, allows for lower prices and improved international competitiveness that further boosts exports. Conversely, reduced exports cause a vicious cycle of declining demand, output and productivity growth. Balance-of-paymentsconstrained growth (BPCG) models, following Thirlwall (1979), emphasize the need for developing countries to export in order to be able to import the machinery, capital equipment and technology required for productivity gains and sustained output growth.

The simplest form of BPCG-models, known as "Thirlwall's law", can be expressed as

$$
y_{i}=\frac{\eta_{x_{i}} y^{*}}{\eta_{m_{i}}}
$$

where $y_{i}$ is the growth rate of developing country $i, \eta_{i}$ is the world's income elasticity of demand for exports from country $i, \eta_{i}$ is the income elasticity of demand for imports by country $i$, and $y^{*}$ is the rate of world income growth (Thirlwall, 1979). According to equation (1), growth in country $i$ is determined by the ratio of export growth to the income elasticity of demand for imports. Applied to secular stagnation, the equation implies that developing countries that face declining export earnings from protected economic slump in developed countries are unable to sustain growth.

The relationship in equation (1) is subject to a number of assumptions, including a balanced trade account, constant relative prices (i.e. purchasing-power parity) and the Marshall-Lerner condition being just satisfied (i.e. the sum of the price elasticities of demand for imports and exports equals unity), so that the growth of exports is solely determined by the growth of world income. One consequence of these assumptions is that ELCC-effects are ruled out. As further explained below, this is because cumulative-causation effects from improved price competitiveness (i) are small when the price elasticity of export demand is low, (ii) do not occur when purchasing-power parity (PPP) holds and nominal exchange-rate appreciation crowds out the increase in international competitiveness. 
Nonetheless, the two traditions share a sufficient number of considerations about the crucial role of exports in facilitating demand-led growth for them to be combined when the strong assumptions of BPCG-models are relaxed. ${ }^{10}$ Starting with exports, export demand may be assumed as determined by the real exchange rate and foreign income, which in terms of growth rates can be specified as follows:

$$
\mathrm{x}=\varepsilon_{x}\left(e+p^{*}-p\right)+\eta_{x} y^{*}
$$

where $x$ denominates exports; $e$ reflects the nominal exchange rate (measured in home currency per unit of foreign currency); $p$ and $p^{*}$ are domestic and foreign price indices, so that $\left(e+p^{*}-p\right)$ represents real exchange-rate depreciation (or the increase in the relative price of foreign goods); $y^{*}$ is foreign (i.e. rest of the world) income, and $\varepsilon_{x}$ and $\eta_{x}$ are the price and income elasticities of export demand $\left(\varepsilon_{x}, \eta_{x}>0\right)$.

Foreign price inflation is assumed as exogenous, while domestic price inflation reflects changes in unit labour costs and in the gross profit mark-up:

$$
p=\tau+w-q
$$

where $\tau$ is the change in the mark-up over unit labour costs, $w$ is wage inflation, and $q$ is labour productivity growth. It may be assumed that $\tau=0$ and that labour productivity growth is determined endogenously according to an aggregate version of Verdoorn's law (i.e. due to increasing returns of scale, aggregate labour productivity is a positive function of the pace of output growth), so that:

$$
q=q_{0}+\alpha y
$$

where $q_{0}$ is a shift factor representing autonomous technological change, including as a result of technology policies, $\alpha$ represents the Verdoorn effect, and $q_{0}, \alpha>0$.

The growth rate of aggregate demand $y$ is then determined by the weighted average of the growth rates of exports and autonomous domestic demand multiplied by the Keynesian multiplier $\lambda$, i.e.

$$
y=\lambda\left(\omega_{a} a+\omega_{x} x\right)
$$

\footnotetext{
${ }^{10}$ Part of the following account follows Blecker (2013) but also incorporates Moreno-Brid (1998, 1998-1999) and Razmi $(2011,2013)$ who themselves draw on a significant number of earlier contributions.
} 
where $a$ is the growth rate of autonomous domestic expenditures and $\omega_{a}$ and $\omega_{x}$ are the shares of domestic expenditures and exports in total demand. In the logic of BPCG-models, exports constitute the only demand source that simultaneously relaxes the balance-of-payments constraint and stimulates output growth. All the domestic sources of demand would worsen the balance of payments because their contribution to output growth would raise imports beyond a sustainable level.

To see this, an import demand function with constant elasticities may be expressed as

$$
m=-\varepsilon_{m}\left(e+p^{*}-p\right)+\eta_{m} y
$$

where $m$ represents import growth, $\varepsilon_{m}$ and $\eta_{m}$ are the price and income elasticities of import demand, and $\varepsilon_{m}, \eta_{m}>0$.

Following McCombie and Thirlwall (1997) and Moreno-Brid (1998, 1998/1999), financial flows may be added, to allow for non-zero trade balances. Accordingly, a country's balanceof-payments position is assumed to reflect a constant ratio of its trade balance (surplus or deficit) relative to national income, where the level at which a trade deficit can be sustained is assumed to reflect the degree of confidence by international financial investors. ${ }^{11}$ This implies that

$$
\theta(x-y)=e+p^{*}-p+m-y
$$

where $\theta$ is the initial ratio of exports to imports (both measured in domestic currency). Setting $\theta=1$ would reflect the traditional assumption of trade balance as a special case. This special case is clearly important for developing countries with relatively shallow domestic financial markets and little access to international financial markets, while it is less important for financially integrated economies. Assuming domestic-demand growth to be constrained by its need for imports, reflecting the view that exports are the only truly autonomous source (and, by the same token, exogenous constraint) of aggregate demand, it is equation (7) that determines the rate of output growth while the rate of domestic expenditure growth $a$ in equation (5) becomes endogenous in the long term.

Substituting equations (2), (3), (4) and (6) into equation (7) and assuming $\tau=0$, i.e. no change in mark-ups, yields a very general expression for the BPCG- rate, $y_{B}$ :

\footnotetext{
${ }^{11}$ To simplify, the trade balance is assumed to equal the current-account balance.
} 


$$
y_{B}=\frac{\left(\theta \varepsilon_{x}+\varepsilon_{m}-1\right)\left(e+p^{*}-w+q_{0}\right)+\theta \eta_{x} y^{*}}{\eta_{m}-1+\theta-\alpha\left(\theta \varepsilon_{x}+\varepsilon_{m}-1\right)}
$$

In addition to Thirlwall's law, reflected in equation (1), this expression includes a non-zero trade balance, which allows for exogenously determined capital flows to loosen or tighten the external growth constraint, and an aggregate version of the Verdoorn effect to allow for export-led cumulative causation. The latter, in turn, implies assuming PPP not to hold, in order to capture effects from changes in international price competitiveness, as well as assuming the extended Marshall-Lerner condition to hold, in order to capture effects from the price elasticity of exports and imports and preserving the Verdoorn effect in the equation. Accordingly, the equation sees real income growth as determined by the rate of expansion of the world economy and the income elasticities of exports and imports, as in Thirlwall's law, but also by the initial trade balance and the effects of capital flows, the price elasticities of exports and imports, the Verdoorn effect, and terms-of-trade movements.

Following Moreno-Brid (1998, 1998/1999), the combinations of real income growth $(d y / y)$ and import growth $(\mathrm{dm} / \mathrm{m})$ that equation $(8)$ reflects may be graphically represented as in chart 1. Line B is given by the solutions of equations (2) and (7) and depicts the set of combinations of income and import growth consistent with keeping constant the trade deficit as a proportion of income. In this case, changes in income growth are sustainable if:

$$
\left.d(d y / y) / d t=\sigma\left(d m / m-\theta \eta_{x} d y^{*} / y^{*}-\left(\varepsilon_{x} \theta+1\right)\left(d p / p-d p^{*} / p^{*}\right)-(1-\theta) d y / y\right)\right), \text { with } \sigma>0
$$

Its slope is equal to $(1-\theta)$, i.e. not greater than one and positive (as in chart 1) when the trade account is in deficit. Depicting it with a positive intercept reflects a situation of constant terms of trade and an expanding world economy. Points below (above) line B have a decreasing (increasing) ratio of the trade deficit relative to income.

Line $\mathrm{Q}$ is the graph of the import demand function given by equation (6) and shows the minimum increase in imports required for any given rate of output growth. Such a minimum increase is sustainable if:

$$
\left.d(d m / m) / d t=\varphi\left(d m / m+\varepsilon_{m}\left(d p / p-d p^{*} / p^{*}\right)-\eta_{m} d y / \mathrm{y}\right)\right), \text { with } \varphi<0 \text {. }
$$

Its slope reflects the income elasticity of imports, assumed to exceed (1- $\theta$ ), and becomes steeper, for example, the more a country relies on import-intensive processing exports rather than on exports with a high domestic value-added content. The slope of line $Q$ must exceed 
that of line $B$ if economic growth faces a balance-of-payments constraint. Its intercept at the origin mirrors the assumption of constant terms of trade. To the right (left) of $\mathrm{Q}$ the growth path of real income is associated with a decreasing (increasing) import-income ratio. The intersection of lines B and Q determines the growth rates of real income and real imports consistent with a constant ratio of the trade deficit relative to income.

Chart 1: Effects of secular stagnation in developed countries on developing country growth

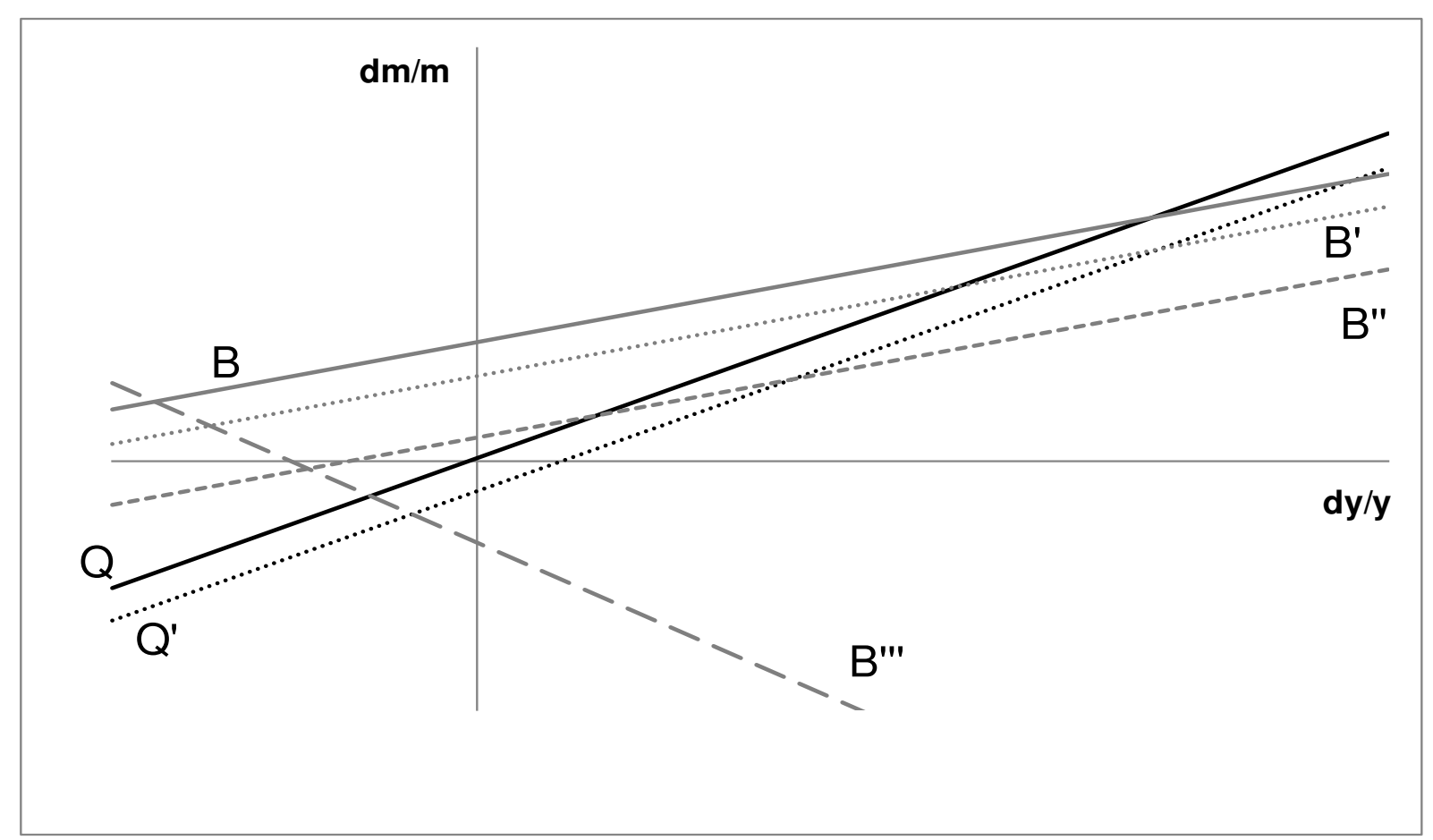

Source: Author's elaborations on Moreno-Brid (1998 and 1998/1999).

Deterioration in a developing country's external economic environment associated with secular stagnation in developed countries has the following effects. First, a deterioration of the terms of trade, such as resulting for natural resource-rich economies from an exogenous decline in commodity prices, causes a parallel downward shift of lines B and Q to B' and Q' (i.e. the two dotted lines in the figure) with the final growth effect depending on the initial export-import ratio and the price elasticities of imports and exports, as specified in equation (9). Second, a slowdown in global economic growth results in a downward shift of line B to B" (i.e. the grey line with short dashes in the figure) for two reasons: (i) in the logic of BPCG-models, lower export revenues cause reduced imports of machinery and capital equipment and the ensuing lower investment growth reduces output growth; and (ii) contrary to the canonical BPCG-model, assuming PPP not to hold and the extended Marshall-Lerner condition to hold, so that the variables specified in equation 4 do not drop out of equation 8 , export-related cumulative causation forces are allowed to work: if export demand declines, 
capacity utilization will decline. This will lead to a decline in productivity growth to the extent that the Verdoorn effect is endogenous to the rate of capacity utilization. Hence, the economy's pace of growth decelerates unless an alternative source of demand can be found. However, greater reliance on that alternative source of growth should not cause an increase in the income elasticity of imports, as this would lead to a counter-clockwise rotation in line $\mathrm{Q}$ (determined by equation (10)) and, unless counterbalanced by changes in other parameters or exogenous variables, lead to a decline in the balance-of-payments constrained growth rate. Third, a reversal of capital flows, e.g. caused by a decline in international financial investors' confidence in the country's growth prospects, e.g. if the country becomes a net capital exporter, makes line B shift from upward to downward sloping and move to B', (i.e. the grey line with long dashes in the chart).

Some of these effects may not occur, or be reversed, depending on the kind of policies developed countries adopt to address the risk of secular stagnation (discussed in section 2). First, measures that increase disposable income of developed country households and stimulate income-financed consumption would increase sustainable capacity utilization and hence private investment. The attendant growth effects would support demand for developing country exports, even though probably not at levels of the pre-crisis period when much of developed-country consumption was debt financed. However, the discussion in section 2 suggests that such an outcome is unlikely. Second, the deterioration of the terms of trade would be (partially) compensated by fiscal expansion concentrated on infrastructure investment, as the relatively high raw-material content of infrastructure investment would increase the consumption of industrial metals and energy and support the international prices of these commodities. This effect would be reinforced if developing countries, especially China, maintain a high rate of urbanization and associated infrastructure investment even with reduced export prospects.

Third, prolonged monetary expansion in developed countries would probably maintain large capital flows to developing countries in search of higher returns and allow for an elevated level of developing countries' income ratio of the trade deficit that international financial investor judge sustainable. These flows can maintain the BPCG-rate at an elevated pace as the net inflow of capital from abroad can be used, instead of export revenues, to pay for imports. However, it will not suspend the external growth constraint over an extended period of time if the associated repayment schedules imply a continuous increase in the income ratio 
of capital inflows, i.e. a situation which will eventually undermine international investors' confidence.

4. Maintaining rapid growth in the South despite secular stagnation in the North: changing assumptions and policies

The previous section examined how secular stagnation in developed countries may affect developing countries' output growth. This section considers how developing countries can maintain output expansion even in a less favourable external economic environment. The first part relaxes the assumptions of traditional BPCG-models that make exports the only autonomous source of demand and block cumulative causation forces and, instead, argues that technology shifts and cumulative-causation effects can result from domestic-demand growth without increasing the import elasticity of demand or causing the income share of the trade deficit to become unsustainable. The second part discusses attendant policy changes.

\section{(a) Changing assumptions}

Traditional BPCG-models exclude relative price effects and cumulative causation by assuming either or both the extended Marshall-Lerner condition not to hold and PPP to hold. The validity of these assumptions is largely an empirical question, where results are mixed and depend on the chosen countries, time periods and empirical techniques. But it seems reasonable to conclude that price elasticities increase over time and satisfy the extended Marshall-Lerner condition, such as through J-curve effects, and that PPP is more likely to hold among structurally similar countries and over the very long run. ${ }^{12}$ Accordingly, relative price effects, technology shifts and cumulative causation may well play a role in a NorthSouth setting in the short to medium term, so that output growth is no longer just a function of developed country growth, developing countries' income elasticities of demand for exports and imports and the level of the trade deficit that these countries can sustain.

\footnotetext{
12 The literature review by Bahmani, Harvey and Hegerty (2013) concludes that supportive evidence for the Marshall-Lerner condition to hold is much weaker than commonly thought. However, the review mainly refers to developed countries. It is well-known that for these countries intra-industry trade plays an important role, as well as that non-price factors are crucial for such trade. It is also important to note the widespread perception that exchange-rate undervaluation is an effective industrial policy in tradable goods sectors of developing countries. This suggests that their exports are price sensitive, which provides prima facie evidence for the Marshall-Lerner condition to hold.
} 
Relaxing the assumption that the extended Marshall-Lerner condition does not hold and, instead, allowing relative price effects to play a role, exports cease to be the only exogenous driver of demand and both exports and domestic demand are sources of output growth (see also Razmi, 2013). Recognizing that, via the technology shift factor and the Verdoorn effect, an increase in domestic investment simultaneously raises aggregate demand and labour productivity, labour productivity growth improves international price competitiveness. If exports are price elastic, this competitiveness effect raises exports and alleviates any balanceof-payments constraint that the initial increase in investment may have caused. Hence, whether or not domestic-demand growth based on increased investment worsens the balanceof-payments position depends on the import elasticity of investment.

But exchange-rate changes also play a role. Also relaxing the assumption that PPP holds, and instead assuming fully flexible exchange rates, implies that any growth in exports from cumulative causation that exceeds the increase in imports triggered by growing investment will be crowded out to keep the income ratio of the trade account unchanged (or, in the absence of capital flows, balanced). This may occur through exchange-rate appreciation, or a rise in domestic prices (such as from real wage growth in excess of productivity growth). In reality, countries are unlikely to adopt free floating and growth effects will result from cumulative causation and global income growth to the extent that managed floating succeeds in maintaining at least part of the increase in international competitiveness.

To further examine the output effects of labour productivity growth, the implicit assumption of BPCG-models that foreign and domestic goods are imperfect substitutes may be relaxed. ${ }^{13}$ Assuming instead that importables (exportables) are also produced (consumed) domestically, an exchange-rate appreciation will worsen the external balance due to substitution effects between importables and exportables on both the supply and demand side. The size of these effects will depend on exchange-rate flexibility and the country's pattern of specialization.

More importantly, labour productivity growth resulting from technology shifts and/or the Verdoorn effects may have positive or negative impacts on a country's BPCG, depending partly on whether that technological progress responds to domestic-demand or export growth, and partly on the country's economic structure. To see this, equation (8) may be extended by disaggregating the shift factor representing autonomous technological change $\left(q_{0}\right)$ into the

\footnotetext{
${ }^{13}$ Razmi (2011) provides a detailed discussion of the algebra of these effects, though with a different focus. The spirit of assuming substitutability is similar to that in Riedel's (1984) criticism of Lewis (1980).
} 
BPCG-effect stemming from the export sector, which depends on the size of the technology advance and the share of exports in total demand and may be denoted as $q_{x \omega x}$, and that related to domestic demand (i.e. $\left.q_{a \omega a}\right)$. Similarly, the size of the Verdoorn effect $(\alpha)$ depends on whether it responds to export or domestic-demand growth and on the relative size of these two elements of aggregate demand, i.e. $\alpha_{x \omega x}$ for exports and $\alpha_{a \omega a}$ for domestic demand. Moreover, the impact on BPCG of export and domestic-demand growth also depends on the import elasticity of demand of these two elements, i.e. $\eta_{m x \omega x}$ for exports and $\eta_{\text {mawa }}$ for domestic demand. How this disaggregation affects BPCG can be expressed as follows:

$$
y_{B^{\prime}}=\frac{\left(\theta \varepsilon_{x}+\varepsilon_{m}-1\right)\left(e+p^{*}-w+\left(q_{x} \omega_{x}+q_{a \omega_{a}}\right)\right)+\theta \eta_{x} y^{*}}{\left(\eta_{m_{x} \omega_{x}}+\eta_{m_{a} \omega_{a}}\right)-1+\theta-\left(\alpha_{x \omega_{x}}+\alpha_{a \omega_{a}}\right)\left(\theta \varepsilon_{x}+\varepsilon_{m}-1\right)}
$$

Concentrating on domestic-demand growth, equation (11) indicates that a rebalancing from export to domestic-demand growth maintains the pace of BPCG if the import elasticity of domestic demand does not exceed that of exports $\left(\eta_{\text {ma }} \leq \eta_{m x \omega x}\right)$ or make the trade deficit as a proportion of income $(\theta)$ unsustainable, and if labour productivity growth from technology shifts and Verdoorn effects of growing domestic demand are at least as strong as those from exports $\left(q_{a \omega a}, \alpha_{a \omega a} \geq q_{x \omega x}, \alpha_{x \omega x}>0\right)$. The direction and strength of these effects are determined by relative price effects (assuming $\theta \varepsilon_{x}+\varepsilon_{m}>1$ ), changes in the size of output, and changes in the exchange rate and wages.

\section{(b) Changing policies}

This section examines the policy changes required to achieve the changes in the import elasticity of demand and in labour productivity growth that could compensate for lower export growth by faster domestic-demand growth.

Differences in the import elasticity of the different demand components imply that changed proportions of exports and domestic demand - and of household consumption, government expenditure and investment in domestic demand - determine changes in the import elasticity of aggregate demand growth. These relations depend on a country's economic structure. The import elasticity of exports is likely to be highest for countries that are strongly involved in processing trade, and lowest for commodity exporters. The import elasticity of domestic demand is generally lowest for government consumption, while the import content of 
investment and household consumption depends on a country's industrial development, i.e. the extent to which its production structure matches the emerging composition of consumption and is sufficiently advanced to produce machinery and capital equipment.

Export-led growth allows financing required capital-goods imports from export earnings. A rebalanced growth strategy needs to find alternative sources. First, remaining export earnings could be used. Second, developing countries' foreign-exchange reserves from currentaccount surpluses during the export-led growth period appear outsized relative to a variety of traditional metrics, such as months of imports and short-term external liabilities. Tapping into these reserves could finance capital-goods imports for a significant period of time on average, though certain individual countries would rapidly face constraints. Third, development banks could intermediate concessionary lending from countries with large to those with few foreign-exchange reserves. The New Development Bank recently established by the BRICS could play a crucial role here. ${ }^{14}$ Fourth, another source is remittances from migrants that developed countries may welcome to slow down the decline of their labour force also in the form of high-skilled workers that originate from other than the least-developed countries. Finally, less risky forms of foreign finance, such as foreign direct investment, long-term bonds denominated in local currency and/or with repayment schedules that alter in the event of pre-specified contingencies could also be used. However, in terms of the borrowing country's balance sheet, the income-generating capital on the asset side must match the interest, dividend and amortization payment commitments generated on the liability side. ${ }^{15}$

The viability of using such alternative sources to finance capital-goods imports depends on two elements. First, the foreign capital lending must be used to create real capital, i.e. for investment that ensures growth so that the share of foreign lending in GDP does not rise and the repayment profile of lending does not deteriorate. If, instead, capital inflows create financial capital by raising asset prices in the real-estate and equity markets, ensuing wealth effects may allow consumers to expand debt-financed consumption. This would lift output through the contribution of domestic consumption to aggregate demand growth. But it would do so through increased debt rather than increased income, causing vulnerabilities related to rapid domestic credit expansion, exchange-rate appreciation and excessive financial-market

\footnotetext{
${ }^{14}$ Enhanced South-South and regional monetary integration could play an important role in growth rebalancing, but this issue goes beyond the scope of this paper.

${ }^{15}$ For detailed discussion of this issue, see Kregel (2004).
} 
volatility that in the event of a capital-flow reversal need to be combatted by tighter macroeconomic policies with adverse growth effects.

Second, the sustainability of using such alternative sources also depends on the amount of required capital-goods imports, the availability of foreign exchange from remittances and remaining exports, and the maturity and repayment structure of any required loans. Addressing these two elements, may involve policies, such as specific incentive schemes, that ensure that the new investment match the requirements for producing consumer goods in sectors with cumulative causation effects, as well as some control over the amount of capital that enters the country and its performance conditions.

Turning to labour productivity, most positive effects stem from fixed capital investment (with the remainder resulting from human-capital development). The autonomous element of investment is generally low and mainly reflects replacing obsolete machinery, as well as public investment following fiscal expansion. The bulk of investment responds to expected higher earnings from higher expected sales and profits raising the marginal efficiency of capital. With reduced prospects for export growth, expected expansion of household consumption becomes a key driver of investment, for two reasons.

First, household consumption is the largest component of domestic demand. In most developing countries, household consumption accounts for half to two-third of aggregate demand so that even a relatively small proportional increase in household consumption makes a significant contribution to aggregate demand growth. To illustrate the importance of these proportions, it is useful to recall that in China, where the share of household consumption in GDP has been only about 36 per cent over the past decade, net exports contributed 2.3 percentage points and household consumption 4.1 percentage points to the growth rate of GDP of 14.2 per cent in 2007 , i.e. the year before the great trade collapse. Assuming government expenditure and investment to remain unchanged, this means that the absolute amount of household consumption would have needed to grow by slightly more than half of any decline in net exports in order to maintain GDP-growth at the pace of 2007. This would have corresponded to roughly 5 per cent of total household consumption expenditure in 2007 , compared to an actual increase in household consumption spending by 8.5 per cent between 2006 and 2007.

Second, the composition of household consumption can drive investment in large-scale manufacturing. Developing countries' rapid income growth over the past two decades has 
allowed many of them to attain levels of per capita income where consumer demand shifts from basic necessities, such as food, to discretionary items, such as manufactured consumer goods. The largest among these countries are approaching levels of domestic purchasing power that can generate sufficiently large and rapidly rising domestic demand for such consumer goods. This would allow domestic manufacturers to deepen the division of labour and realize increasing returns to scale and growing labour productivity, generating much the same process of cumulative causation as emphasized by ELCC-models. Indeed, more general cumulative causation models, such as Hirschman (1958) and Myrdal (1957), emphasize diversified growth strategies and argue that net exports are only one source of demand for manufactures. Growth in consumption will generate cumulative causation effects similar to those from exports provided that the attendant investment and output growth allows producing with increasing returns to scale and induces productivity growth. Post-Keynesian consumption theory holds that the income elasticity of consumer demand is subject to threshold effects and empirical estimates suggest that a range of developing countries currently are at levels of per capita income where this elasticity increases rapidly (Mayer, 2013b). Enhanced South-South integration could further enhance the market size for developing country producers.

Investment is likely to respond to rising domestic consumption especially in those developing countries that have followed an export-led strategy. These countries master large-scale manufacturing activities but, emphasizing developed countries as destination markets, their production structure is strongly influenced by the preferences of consumers with a relatively high level of per capita income. Meeting domestic-demand growth will need to take into account that consumers in developing countries have lower levels of disposable income and, hence, will demand goods with lower prices but also accept lower levels of product quality. Resulting domestic production in the less-sophisticated market segments of such consumer goods is unlikely to face stiff competition from imports because consumers are mostly concerned about price, rather than quality, and developed country firms do not usually compete in these segments. ${ }^{16}$ Accordingly, the import elasticity of demand from this type of domestic-demand growth is probably low and reduces the aggregate import elasticity of demand, thereby allowing for higher BPCG. By contrast, middle-range market segments of consumer goods tend to see significant competition between developed and developing

\footnotetext{
${ }^{16}$ Stiff competition is also unlikely in the upper-range market segments where the brand names of developed country producers are important.
} 
country firms because developing country firms can sufficiently improve the quality of their goods and developed country firms can sufficiently reduce their production costs to compete in these segments. ${ }^{17}$ Hence, stimulating domestic investment to build competitive production in these segments will be more challenging.

Regarding technology-shift, there is little reason to believe that innovation designed to provide affordable access to new goods tailored to the needs of lower-middle-income consumers generates less technological progress than innovation targeting more expensive standardized goods for export. ${ }^{18}$ But the size of productivity gains from domestic-demand growth crucially depends on the Verdoorn effects, which are determined by output growth and attendant cumulative causation. The net impact on productivity gains from Verdoorn effects resulting from growth rebalancing partly depends on the loss of productivity gains from reduced export growth. Manufacturing firms that export are generally more productive than non-exporting firms. However, there is strong theoretical support (e.g., Redding, 2011) and significant empirical evidence (e.g., Wagner, 2012) indicating that only relatively few firms are directly involved in trade and that high productivity is a pre-condition for export participation, rather than its outcome. It is self-selection that makes more productive firms engage in export activities, as it is only those firms that can absorb the additional sunk costs associated with learning about demand and setting up distribution networks on export markets. Once such already highly productive firms engage in exporting, they may further improve productivity through learning effects. However, "there is little evidence supporting 'learning-by-exporting”’ effects (WTO, 2013: 87).

Two additional results from the empirical literature are noteworthy. First, some studies indicate that the size of any learning-by-exporting effects depends on the income level and market size of the destination country. Exporters adjust the quality of their products across destinations by varying the quality of their inputs, so that productivity gains are persistently higher for firms that export higher-quality goods to high-income and larger countries (Manova and Zhang, 2012). This would signal a substantial loss of Verdoorn effects from reduced prospects for exports to developed countries. However, second, most of the benefits from productivity increases after export entry are passed on to buyers in the form of lower prices (Marin and Voigtländer, 2013). This finding suggests that productivity increases from

\footnotetext{
${ }^{17}$ For more detailed discussion of market segmentations in consumer goods, see Mayer (2013a).

${ }^{18}$ While there is a lacuna of empirical work on this issue, the related literature on inclusive innovation (e.g., Chataway, Hanlin and Kaplinsky, 2013) supports this perspective.
} 
growing exports do generally not transform into higher profits that could be used for further investment, which would be how Verdoorn effects are reflected. But it also means that Verdoorn effects in middle-range goods produced for domestic markets may well be positive, provided that productivity growth is allowed to translate into higher profits and investment rather than lower prices. ${ }^{19}$

Moreover, positive Verdoorn effects are likely to occur from the less-sophisticated market segment. Here, new products would be produced so that domestic producers may face rising expectations from domestic consumers that could engender learning effects similarly to those from exports to developed countries. ${ }^{20}$ Such Verdoorn effects would combine with positive technology-shift effects and be akin to a non-tradables sector with faster productivity gains relative to the tradables sector. These gains tend to cause exogenous real exchange rate depreciation in equation (8). Allowing relative price effects to work, the attendant substitution effects will further reduce the import elasticity of demand.

Whether productivity growth from domestic-demand growth eventually lowers or raises BPCG also depends on exchange-rate movements and wage growth relative to productivity growth. As illustrated in equation (11), any productivity growth in the exportables sector can translate into increased international competitiveness and faster export growth only if it is not eroded by currency appreciation or wage increases. The same holds for productivity growth in the importables sector, with one important difference. The proportion of productivity growth in least-sophisticated market segments, combined with their size, and that of the middle-range market segments determines the size of real exchange rate depreciation and the changes in competition caused by an increase in domestic consumer demand. If this proportion is large, exchange-rate changes and domestic wage growth will have little adverse effects on the competitiveness of domestic producers in middle-range market segments and the positive effect of domestic demand growth on the BPCG will be relatively large. By contrast, if the proportion is small, any exchange-rate appreciation or domestic wage growth will cause a leakage of domestic demand growth to imports. While exchange-rate management can contain this leakage, wage effects are more difficult to manage. This is because wages are not only a cost element but also a driver of disposable income and hence consumer demand. Indeed, an increase in wages commensurate to average aggregate

\footnotetext{
${ }^{19}$ One way to make this possible without losing price competitiveness vis-à-vis foreign suppliers is through exchange-rate policy.

${ }^{20}$ Findings that R\&D-spending is pro-cyclical (e.g. Barlevy, 2007) indicate that striving for productivity growth, such as through the development of new products, may well respond to expected demand growth.
} 
productivity growth will be necessary to ensure that domestic demand growth is driven by income rather than debt-financed consumption. On the other hand, productivity growth of innovative firms in middle-range market segments cannot be fully translated into wage growth in order to prevent an erosion of their increase in international competitiveness. But fiscal measures can increase the non-wage elements of disposable income and purchasing power of workers in these firms.

The effects associated with the above discussion may be illustrated by chart 2 . The real exchange rate depreciation stemming from productivity gains in less-sophisticated consumergood segments imply a parallel downward shift of lines B and Q to B' and Q'. The slope of Q' is flatter than that of Q because the import elasticity of demand decreases as there is little substitutability between domestically produced and imported goods in this sector. The substitution effects in the middle-range market segment reduce the slope of the import demand function further, and line Q' moves towards line Q' but the extent of this move from consumer goods will be tempered by a potential increase in the income elasticity of import demand from capital goods. The slopes of lines B and B' are identical, assuming capitalaccount and exchange-rate management to succeed in maintaining exchange-rate stability at its new, depreciated level. Overall, the import elasticity of demand falls for any given growth rate. This indicates that developing countries could maintain rapid growth in spite of secular stagnation in developed countries.

Chart 2: Potential effects of a rebalancing of developed countries' growth strategy on their balance-ofpayments constrained growth rate

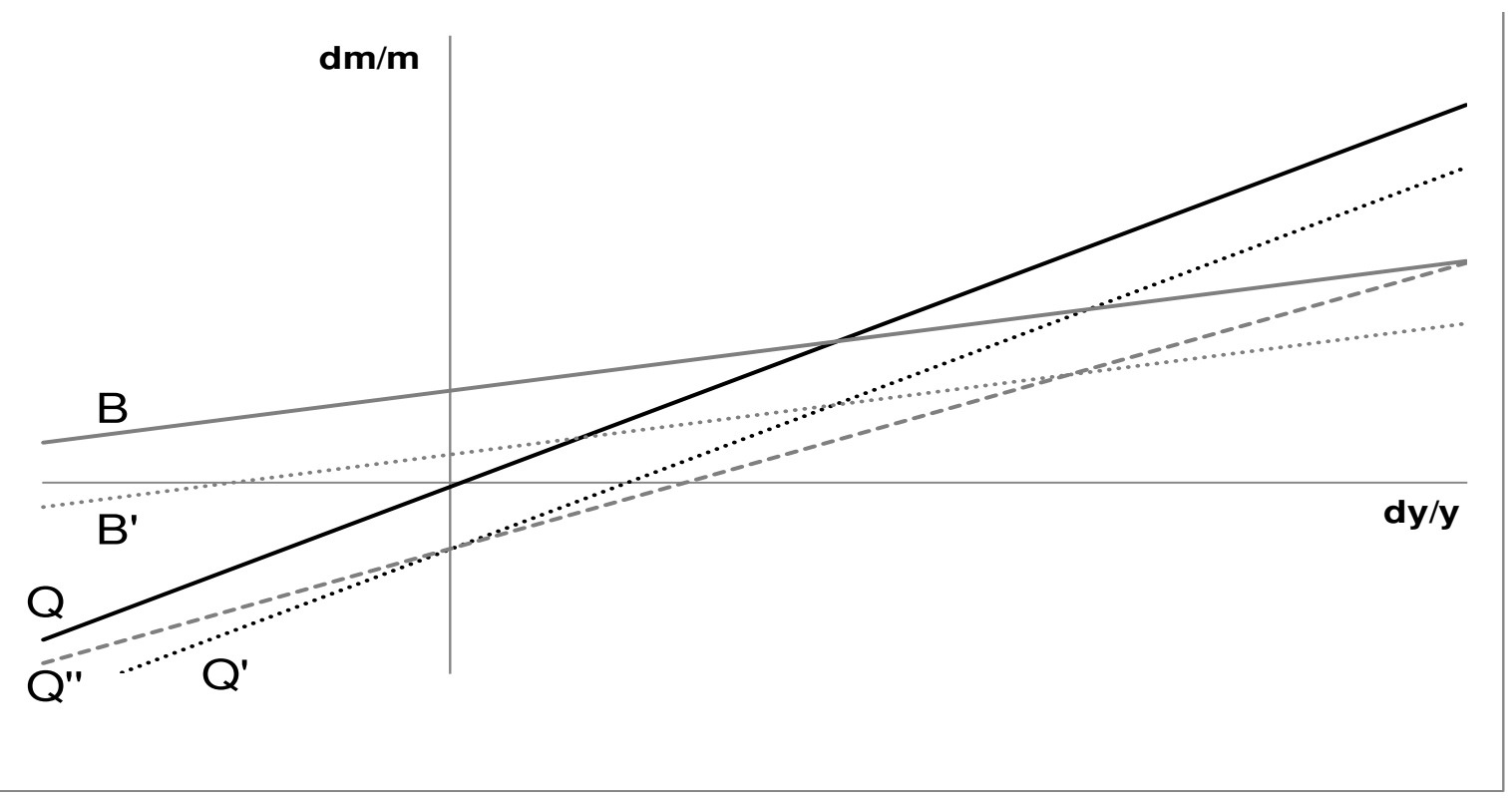

Source: Author's elaboration. 
Benefitting from these effects will be complicated to the extent that developed countries address the risk of secular stagnation by increasing their exports to developing countries, through competitiveness effects stemming from wage restraint or exchange-rate depreciation or through gains in market access from trade agreements. However, such an outcome would not be sustainable because developed countries would not address the roots of secular stagnation and developing countries would be unable to create the income and require purchasing developed-country goods from borrowing. Indeed, this outcome would risk putting the global economy, rather than just developed countries, at risk of secular stagnation.

\section{Conclusions}

There remains considerable controversy over why economic recovery from the 2007-2008 crisis has remained so sluggish across the main developed countries. If it reflects a sustained lack of aggregate demand, i.e. secular stagnation, developing countries cannot maintain rapid growth based on export-led strategies.

Demand-based growth models indicate that developing countries can sustain rapid growth by compensating for lower export growth by faster domestic-demand growth, provided that they can also reduce the import elastictity of demand. One way of achieving this is accelerating investment in consumer-good sectors that are sufficiently large to allow for rapid productivity growth from cumulative causation. Capital-account and exchange-rate management needs to avoid erosion of the associated gains in international competitiveness through currency appreciation. Wage growth should be commensurate to average aggregate productivity gains to finance domestic-demand growth through income growth, rather than borrowing, but cannot fully compensate productivity gains of the most innovative firms to prevent an erosion of their gains in international competitiveness through wage inflation. Fiscal measures can increase the non-wage elements of disposable income and further raise consumers' purchasing power.

The extent to which growth rebalancing is successful partly depends on an economy's size and economic structure. Small economies are unlikely to attain sufficiently rapid output growth to benefit from cumulative-causation effects on the basis of domestic-demand growth, so that an increase in their market size through South-South integration is of critical importance. Resource-based economies will also find it challenging to rapidly create large 
manufacturing activities. But to the extent that commodity prices remain at historically elevated levels, these countries will continue enjoying a relatively favourable external economic environment, giving them more time for economic restructuring.

The success of growth rebalancing also depends on how developed countries address the risk of secular stagnation. While policymakers dispose of a wide array of measures, continued monetary expansion and a sizable contribution of exports, including to developing countries, are likely to play important roles. Monetary expansion is likely to trigger capital flows to developing countries which, for developed countries, would be associated with declining real exchange rates, increased competitiveness, and increased export demand. Demand for developed-country exports may be further strengthened through trade agreements. The result for developing countries would be the risk that any acceleration of domestic-demand growth causes an increase in the import elasticity of demand, reflected by growing imports. Expanding domestic production in order to allow domestic-demand growth be financed through growing income, rather than borrowing, would become very difficult. Hence, developing countries may be well advised to combine accelerated investment in large consumer-good sectors with capital-account and exchange-rate management to contain capital inflows and, more generally, to manage currency values to maintain competitiveness. Drawing down outsized foreign-exchange reserves and obtaining concessionary loans from development banks could finance needed capital-goods imports. All of these policies are fraught with uncertainties and risks. Yet, the alternative may be secular stagnation globally. 


\section{References}

Bahmani M, Harvey H and Hegerty S (2013). Empirical tests of the Marshall-Lerner condition: a literature review. Journal of Economic Studies, 40(3): 411-443.

Barlevy G (2007). On the cyclicality of research and development. American Economic Review, 97(4): 1131-1164.

Blanchard O, Dell'Ariccia G and Mauro P (2014). Rethinking macro policy II: getting granular. In Akerlof G, Blanchard O, Romer D and Stigitz J, eds, What Have We Learned? Macroeconomic Policy after the Crisis. MIT Press, Cambridge and London.

Blecker RA (2013). Long-run growth in open economies: export-led cumulative causation or a balance-of-payments constraint? In Harcourt G and Kriesler P, eds. Handbook of PostKeynesian Economics, Volume I, Oxford, Oxford University Press.

Cline WR (2010). Exports of manufactures and economic growth: the fallacy of composition revisited. In Spence M and Leipziger D, eds., Globalization and Growth - Implications for a Post-Crisis World. Commission on Growth and Development, World Bank, Washington DC.

Edwards L and Lawrence RZ (2013). Rising Tide. Is Growth in Emerging Economies good for the United States? Washington DC, Peterson Institute for International Economics.

Gordon RJ (2014). The turtle's progress: Secular stagnation meets the headwinds. In Teulings C and Baldwin R (2014). Secular Stagnation: Facts, causes and Cures. Centre for Economic Policy Research (CEPR), VoxEO.org eBook.

Hansen A (1939). Economic progress and declining population growth. American Economic Review, 29(1): 1-15.

Hirschman AO (1958). The Strategy of Economic Development. Yale University Press, New Haven.

Hlatshwayo S and Spence M (2014). Demand and defective growth patterns. The role of the tradable and non-tradable sectors in an open economy. American Economic Review, 104(5): $272-277$.

ILO (2015). Global Wage Report 2014/15. Wages and income inequality. International Labour Office (ILO), Geneva. 
IMF (2014). World Economic Outlook, April. Chapter 3: Perspectives on global real interest rates. International Monetary Fund, Washington, DC.

Kaldor N (1970). The case for regional policies. Scottish Journal of Political Economy, 17(3): 337-348.

Koo R (2013). Balance sheet recession as the 'other half' of macroeconomics. European Journal of Economics and Economic Policies, 10(2): 136-157.

Kregel JA (2004). External financing for development and international financial instability. G-24 Discussion Paper No. 32, United Nations, New York and Geneva.

Krugman PR (2009). How did economists get it so wrong? The New York Times, 2 September. Available at http://www.nytimes.com/2009/09/06/magazine/06Economict.html?pagewanted=all\&_r=0.

Krugman PR (2014a). Four observations on secular stagnation. In Teulings C and Baldwin R (2014). Secular Stagnation: Facts, causes and Cures. Centre for Economic Policy Research (CEPR), VoxEO.org eBook.

Krugman PR (2014b). Inflation targets reconsidered. Available at https://www.ecbforum.eu/up/artigos-bin_paper_pdf_0134658001400681089-957.pdf.

Kumhof M, Lebarz C, Rancière R, Richter AW and Throckmorton NA (2012). Income inequality and current account imbalances. Working Paper No WP/12/08, International Monetary Fund, Washington, DC.

Lewis WA (1980). The slowing down of the engine of growth. American Economic Review, 70(4): 555-564.

Manova K and Zhang Z (2012). Export prices across firms and destinations. Quarterly Journal of Economics, 127(1): 379-436.

Marin AG and Voigtländer N (2013). Exporting and plant-level efficiency gains: it's in the measure. Working Paper 19033. National Bureau of Economic Research, Cambridge (Mass.).

Mayer J (2002). The fallacy of composition: a review of the literature. The World Economy, 25(6): 875-894. 
Mayer J (2013a). Responding to the changing shape of the world economy: consumerspending and export developments in Turkey in a comparative perspective. Ekonomik Yaklaşim, 24: 1-28.

Mayer J (2013b). Towards more balanced growth strategies in developing countries: issues related to market size, trade balances and purchasing power. Discussion Paper No. 213, UNCTAD, Geneva.

McCombie JSL and Thirlwall AP (1997). Economic growth and the balance-of-payments constraint revisited. In Arestis P, Palma G and Sawyer M, eds, Markets, Unemployment and Economic Policy: Essays in Honour of Geoff Harcourt. Routledge, New York.

Mokyr J (2014). Secular stagnation? Not in your life. In Teulings C and Baldwin R (2014). Secular Stagnation: Facts, causes and Cures. Centre for Economic Policy Research (CEPR), VoxEO.org eBook.

Moreno-Brid JC (1998). Balance-of-payments constrained economic growth: the case of Mexico. Banca Nazionale del Lavor Quarerly Review, no. 207: 413-433.

Moreno-Brid JC (1998/1999). On capital flows and the balance-of-payments-constrained growth model. Journal of Post Keynesian Economics, 21(2): 283-298.

Myrdal G (1957). Economic Theory and Underdeveloped Regions. Duckworth, London.

Razmi A (2011). Exploring the robustness of the balance of payments-constraint growth idea in a multiple good framework. Cambridge Journal of Economics, 35(3): 545-567.

Razmi A (2013). Imposing a balance of payment constraint on the Kaldorian model of cumulative causation. Journal of Post Keynesian Economics, 36(1): 31-58.

Redding SJ (2011). Theories of heterogeneous firms and trade. Annual Review of Economics, 3: 77-105.

Riedel J (1984). Trade as the engine of growth in developing countries, revisited. Economic Journal, 94(1): 56-73.

Rudebusch GD and Williams JC (2014). A wedge in the dual mandate: monetary policy and long-term unemployment. Working Paper 2014-14. Federal Reserve Bank of San Francisco. 
Sperling G (2013). The case for a manufacturing renaissance. Remarks at the Brookings Institution. Available

at http://www.whitehouse.gov/sites/default/files/docs/the_case_for_a_manufacturing_renaissan ce_gene_sperling 7-25-2013 final_p....pdf.

Stiglitz JE (2012). The Price of Inequality. Penguin Books, London.

Summers LH (2014a). U.S. economic prospects: secular stagnation, hysteresis, and the zero lower bound. Business Economics, 49(2): 65-73.

Summers LH (2014b). Reflections on the 'New Secular Stagnation Hypothesis'. In Teulings C and Baldwin R (2014). Secular Stagnation: Facts, causes and Cures. Centre for Economic Policy Research (CEPR), VoxEO.org eBook.

Teulings C and Baldwin R (2014). Secular Stagnation: Facts, causes and Cures. Centre for Economic Policy Research (CEPR), VoxEO.org eBook.

Thirlwall AP (1979). The balance of payments constraint as an explanation of international growth rate differences. Banca Nazionale del Lavoro Quarterly Review, 128: 45-53.

Wagner J (2012). International trade and firm performance: a survey of empirical evidence since 2006. Review of World Economics, 148(2): 235-267.

WTO (2013). World Trade Report 2013. World Trade Organisation, Geneva. 